Original Article

\title{
Potential study of Dillenia serrata Thunb. fruit extract from Bali Botanical Garden's collection
}

\author{
I Putu Agus Hendra Wibawa*, I Nyoman Lugrayasa, and Sutomo
}

Research Center of Plant Conservation and Botanic Gardens, Bali Botanic Garden, Indonesia Institute of Science, Indonesia

\section{Abstract}

Dillenia serrata Thunb.is a member of the Dillenia clan which is endemic to Sulawesi. D. serrata fruit is a seasonal fruit and can be used as a cooking ingredient as a sour taste, raw material for several food products such as candied fruit and syrup, and has the potential to be processed into chips and jam. Traditionally, the leaves and bark of D. serrata are also used by the local community as a sprue medicine, fever, wound medicine, treating swelling or inflammation and treating vomiting of blood. It is believed that there are still many untapped benefits from this plant. This study was conducted to determine the effectiveness of D. serrata fruit extract as an antimicrobial that causes disease in humans, and to determine its effectiveness as an antioxidant. The antioxidant test was carried out using the DPPH method while the antimicrobial test was carried out by the agar diffusion method (Kirby-Bauer). The ripe Dillenia fruit was extracted using methanol, the extract was then diluted in various concentrations for the DPPH test The results showed that the $D$. serrata extract had the ability as an antioxidant. The antioxidant activity of fresh fruit extracts was higher than that of dried fruit extracts. D. serrata extract is effective in inhibiting the growth of Pseudomonas aeruginosa, Staphylococcus aureus, and Streptococcus mutans bacteria.

Keywords: Antimicrobial, antioxidant, DDPH.

Received: 4 December 2020 Revised: 16 April 2021 Accepted: 19 April 2021

\section{Introduction}

The Dillenia genus is a member of the Dilleniaceae family which is a tree, shrub, or shrub, which grows spread from Madagascar and the Seychelles Islands in the west, to the north to the Himalayas and southern China, across Southeast Asia and Australasia, to Fiji in the east (Rugayah et al., 1995). This plant is also commonly called simpur, sempur or sempu. The name Dillenia was given after the name of the German botanist, Johann Jacob Dillenius (1687-1747) (Quattrocchi, 2012). These plants are usually in the form of shrubs, shrubs, and evergreen trees, reaching $40 \mathrm{~m}$ in height and up to $125 \mathrm{~cm}$ in diameter. The Dillenia species are monoecious plants that produce attractive flowers and yellow fruit. They can grow from the coast to an altitude of about $2000 \mathrm{~m}$ above sea level. They mostly form large leaves and flowers with few inflorescences (Dickison, 1979). Around the world, this plant genus consists of about 60 species (Kader \&Zeinab, 2015). Their bark is unique in its grayish, reddish brown color, and the wood of several Dillenia species can be used in furniture making (Hoogland, 1952). Several species of this genus also produce edible sweet and sour and astringent fruits (Hoogland, 1952; Jansen et al., 1992; Kerrigan et al., 2011; Lim, 2012; Saha \& Sundriyal, 2012) and are cultivated as ornamental plants (Hoogland, 1952; Kerrigan et al., 2011).

Many of the benefits possessed by plants from this genus, certain species of Dillenia produce red dyes and

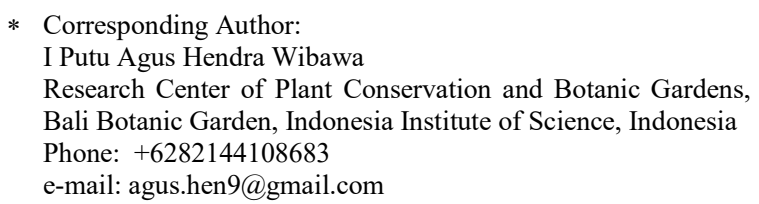

traditional medicinal ingredients (Rugayah et al., 1995). $D$. aurea mixed with several other additives, can be used as a drug to treat thrush, intestinal thrush, and inflammation of the gums (Heyne, 1987). The fruit of several species of Dillenia can be either eaten, fresh or after processing, used as pickles or mixed in cooking. Certain fruits of Dillenia can also be used in shampooing, to get rid of head lice, or to wash clothes (Heyne, 1987; Rugayah et al., 1995). Dillenia plants are known to have good medical value so that people use them as medicine (Kader \& Zeinab, 2015). Certain species such as D. indica, D. obovata, D. ovata and D. suffruticosa are commonly used as ornamental plants in gardens and roadsides (Rugayah et al., 1995).

Dillenia serrata Thunb. is a member of the Dillenia genus endemic to Sulawesi (Kainde, 2011; Pitopang, 2014). This species is well known by the local people of Sulawesi, especially the people of South Sulawesi and Central Sulawesi. The people of South Sulawesi know this plant by the name dengen, while the people of Central Sulawesi know it by the name jongi (Illing, 2017). The shape, size and taste of $D$. serrata fruit are similar to oranges. When ripe, the fruit skin will open on its own like a flower petal. Although the fruit of $D$. serrata is ripe but the taste of the fruit is very sour when eaten directly, therefore this fruit is less attractive and has not been widely used so that it has not been widely cultivated. D. serrata fruit is a seasonal fruit with a relatively short shelf life.

The fruit of $D$. serrata can be used as a cooking ingredient to give sour taste, raw materials for several food products such as candy, and syrup, and has the potential to be processed into sweets, chips and jam (Ilma, 2012; Hasniarti, 2012; Mustafa, 2017). The bark of $D$. serrata is traditionally used by the community as a medicine for fever and wound (Irnawati et al., 2017), treating vomiting of blood (Windardi et al., 2006), and 
treating swelling or inflammation (Jalil et al., 2015). The fruit of $D$. serrata contains citric acid, vitamin $\mathrm{C}$ and beta-carotene compounds (Hasniarti, 2012; Illing, 2017; Irnawati et al., 2017). In addition, this fruit contains secondary metabolic compounds such as alkaloid compounds, flavonoids, saponins, polyphenols and triterpenoids (Gandhi et al., 2013; Bandara et al., 2015; Illing. 2017). It is believed that there are still many untapped benefits from this plant. This study was conducted to determine the effectiveness of $D$. serrata fruit extracts grown in Bali Botanic Gardens as an antimicrobial that causes disease in humans, and to determine its effectiveness as an antioxidant.

\section{Methods}

\section{Plant samples and location}

Dillenia serrata plant samples were taken from the Bali LIPI Botanical Garden Plant Collection. This plant was originally collected from Bancea Village, Pamona Selatan District, Poso, and Central Sulawesi in 1984. In its area of origin, this plant was found to grow at an altitude of $650 \mathrm{~m}$. above sea level. five plants were taken to be used as a living collection (Figure 1).

The research was conducted at the Plant Breeding and Potential Laboratory, Research Center for Plant Conservation and the LIPI Botanical Garden, Bali.

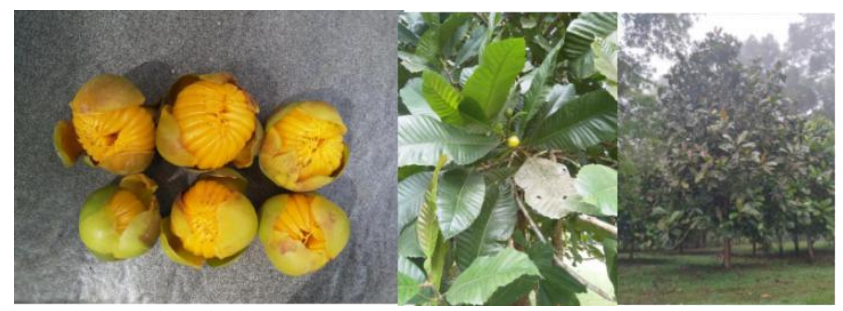

Figure 1. Photograph of D. serrata fruit, flowers and trees

\section{Tools and materials}

The tools used in this research are laminar air flow (LAF), rotary vacuum evaporator, autoclave, spectrophotometer, analytical balance, vortex mixer, mortar, a set of glassware and micropipettes. The materials used in this study were $D$. serrata fruit, absolute methanol, 95\% technical methanol, DPPH $(1,1$ diphenyl-2-pikrihidrazil) and filter paper.

\section{Sample collection and extraction}

The fruit samples used in this study were ripe fruit with a bright yellow color. To make a fresh extract, 100 grams of $D$. serrata fruit are immediately chopped and crushed using a mortar. To make a dry extract as much as 100 grams of $D$. serrata fruit, sliced into thin slices, then oven at $45{ }^{\circ} \mathrm{C}$ for \pm 3 days until completely dry. Each fresh and dry sample was mixed with $1000 \mathrm{ml}$ of methanol. This bath was then left to stand for \pm 3 days in a dark place and room temperature. After 3 days of immersion, it is filtered using filter paper and evaporated using a rotary vacuum evaporator to separate the solvent from the crude extract. The crude extract obtained is then used in further tests.

\section{Antioxidant activity test using the DPPH method}

The antioxidant activity test was carried out according to the method of Chow et al. (2003) with modifications. Each crude extract of $D$. serrata was made into stock solutions with a concentration of 1000 ppm. The stock solution was again diluted into several concentration series, namely: 50;100; 150;200;250; 300 ; and $350 \mathrm{ppm}$. The test was carried out by mixing 1 $\mathrm{ml}$ of each extract concentration with $4 \mathrm{ml}$ of $40 \mathrm{ppm}$ DPPH solution. The mixture is shaken and left for 30 minutes at room temperature in a dark place. As a comparison, ascorbic acid was also calculated for its antioxidant activity, while the concentration variations were: 2 ppm, 4 ppm, 6 ppm, 8 ppm, 10 ppm and 12 ppm. Furthermore, each mixture was measured its absorbance (A) using a UV-Vis spectrophotometer at a wavelength of $517 \mathrm{~nm}$. Quantitative calculations are carried out by determining the inhibitory power of the sample free radicals which are calculated by the following formula:

$$
\text { Th Inhibition }=\frac{\text { (A blanko }-(A \text { sample })}{(A \text { blanko })} \times 100 \%
$$

\section{Antimicrobial test}

Antimicrobial activity testing was carried out using the agar diffusion method (Kirby-Bauer disc diffusion method) (Bauer et al., 1966) which was modified using NA media (nutrient agar). Some of the microbes tested were disease-causing microbes in humans, including Candida albicans, Pseudomonas aeruginosa, Salmonella typhimurium, Staphylococcus aureus and Streptococcus mutans. Observations were made for 1-3 days to see whether there was an inhibition zone formed in the treatment. The inhibition zone diameter was measured to compare the effectiveness of each extract.

\section{Results}

The results of testing for antioxidant activity using DPPH showed that the DPPH solution which was originally purple turned yellowish, this indicates that the extract of $D$. serrata has the ability as an antioxidant. The antioxidant activity of fresh fruit extracts was higher than that of dried fruit extracts. Fresh fruit extract has a value of IC50: 516.70 and dry fruit extract has a value of IC50: 981.58. Meanwhile, ascorbic acid has an IC value of 50: 5.02. The antioxidant ability of $D$. serrata extract is classified as very weak, because its IC50 value is more than 200 ppm (Figure 2).
A

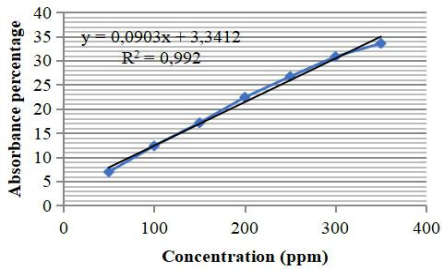

B

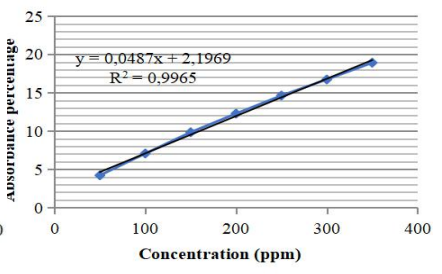

Figure 2. The regression graph of antioxidant testing, (A) fresh fruit extract, (B) dried fruit extract 
The results of the antimicrobial test showed that the two extracts of $D$. serrata were effective in inhibiting the growth of Pseudomonas aeruginosa, Staphylococcus aureus, and Streptococcus mutans but were not effective at inhibiting the growth of Candida albicans and Salmonella typhimurium, The extract is effective in inhibiting bacterial growth seen from the formation of an inhibition zone in the experiment, where this does not happen if the extract is not effective at inhibiting bacterial growth. The antioxidant activity of fresh fruit extracts was higher than that of dried fruit extracts. This can be seen from the ratio of the average diameter formed, where the fresh extract forms a wider average diameter than the dry extract (Table 1).

Table 1. Antibacterial test of D. serrata fruit extract

\begin{tabular}{|c|c|c|c|c|c|c|}
\hline No. & Extract type & $\begin{array}{l}\text { Candida } \\
\text { albicans }\end{array}$ & $\begin{array}{l}\text { Pseudomonas } \\
\text { aeruginosa } \\
\text { (gram-negative) }\end{array}$ & $\begin{array}{l}\text { Salmonella } \\
\text { typhimurium } \\
\text { (gram-negative) }\end{array}$ & $\begin{array}{l}\text { Staphylococcus } \\
\text { aureus } \\
\text { (gram-positive) }\end{array}$ & $\begin{array}{l}\text { Streptococcus } \\
\text { mutans } \\
\text { (gram-positive) }\end{array}$ \\
\hline 1. & Dilenia (fresh fruit extract) & - & + & - & + & + \\
\hline 2. & Dilenia (dried fruit extract) & - & + & - & + & + \\
\hline
\end{tabular}

Information:

1) + : able to inhibit growth

2) -: unable to inhibit growth

\section{Discussion}

The antioxidant activity of the fruit extracts of $D$. serrata may be caused by compounds that act as antioxidants such as: proanthocyanidin, vitamin C (ascorbic acid), and 3,5,7-Trihydroxy-2-(4-hydroxybenzyl)-chroman-4-one. Proanthocyanidin is a polyphenolic compound isolated from the fresh fruit of $D$. indica which shows significant antioxidant activity (Fu et al., 2015). The 3,5,7-Trihydroxy-2- (4-hydroxy-benzyl) chroman-4-one compound which is a flavonoid group is a compound that is an antioxidant in the extract of $D$. indica (Kaur et al., 2016). Irnawati et al. (2017) stated that $D$. serrata juice taken from Lamomea Village, Konda District, South Konawe Regency, Southeast Sulawesi, contains $1.09 \%$ vitamin $\mathrm{C}$ with weak antioxidant activity against DPPH free radicals with a value The IC50 is $161.63 \mathrm{mg} / \mathrm{L}$. Meanwhile, Syahruni\&Nur (2015) stated that $D$. serrata fruit extracts taken from the Malili area, East Luwu Regency, South Sulawesi, showed that ethanol extract, water fraction, ethyl acetate fraction, and hexane fraction had antioxidant activity with an $\mathrm{IC}_{50}$ value respectively 200.9 ppm, 103 ppm, 108.4 ppm and 135.2 ppm.

The antioxidant activity of $D$. serrata extracts grown in the Bali Botanic Garden was classified as very weak. The weak ability of the extract is thought to be due to the low content of antioxidant compounds in the extract. You et al. (2011) stated that the concentration of chemical compounds in plants can be very different depending on various factors such as genetics of cultivar species, season, and location of growth. Cantın et al. (2012) stated that there are large differences in phytochemical profiles between genotypes / cultivars of the same species. The stage of fruit maturity was also reported to affect the total phenolic and anthocyanin contained in the fruit (Wang \& Lin, 2000). Several other studies have also shown that environmental conditions, field maintenance systems, and growing seasons have an impact on antioxidant levels (Howard et al., 2003; Crespo et al., 2010; Kruger et al., 2011).

The antioxidant activity of dried fruit extracts was lower than that of fresh fruit extracts. This may be due to the drying of the fruit using the oven. When temperatures set too high in the extraction process it can cause damage to several groups of plant compounds (Margaretta et al., 2011; Yuliantari et al., 2017; Chairunnisa et al., 2019).

When compared with the $\mathrm{IC}_{50}$ value of ascorbic acid, $D$. serrata extract has a much lower activity; this is presumably because $D$. serrata extract is still a crude extract (not a pure compound) which still contains many other compounds that are not antioxidants. with ascorbic acid which is a pure compound that does have antioxidant properties. The antioxidant effect on $D$. serrata may not only result from a single antioxidant vitamin, but can be generated from a synergistic combination of various antioxidants (Cao et al., 1998).

D. serrata extract can inhibit bacterial growth possibly because the extract contains compounds that are anti-bacterial. Nick et al., (1995) stated that the antibacterial activity of $D$. papuana, which is in the same genus as $D$. serrata, is derived from triterpenoid acid compounds. Triterpenoid acid compounds such as Betulinic acid, Dillenic acid A, Dillenic acid B, Dillenic acid C, Dillenic acid D, Dillenic acid E, 3-Oxoolean1,12-dien-30-oic acid, and 3-Oxoolean-12-en -30-oic acid derived from the plants D. papuana and $D$. philippinensis is a compound reported to have antibacterial properties (Nick et al., 1994;Nick et al., 1995b; Ragasa et al., 2009).

Plants that are closely related tend to produce similar metabolites, so it is possible that D. serrata also produces triterpenoid acid compounds which are antibacterial. Each secondary metabolite compound has a different way of working (Ningsih, 2017). The mechanisms of action of secondary metabolites include inhibiting nucleic acid synthesis, inhibiting cell membrane function, and inhibiting energy metabolism (Ernawati, 2015).

\section{Antibacterial and anti-fungal activities of Dillenia spp.}

Several other Dillenia species are also reported to have antibacterial and antifungal properties such as $D$. indica (Apu et al., 2010; Alam et al., 2011; Jaiswal et al., 2014), D. papuana (Nick et al., 1995a) , D. pentagyna (Haque et al., 2008), D. suffruticosa (Wiart et al., 2004) and D. sumatrana (Grosvenor et al., 1995b). Extracts of 
D. indica, D. papuana, D. pentagyna, D. suffruticosa, and $D$. sumatrana were reported to have growth inhibition against Gram positive and negative bacteria (Sabandar et al., 2016). However, they showed weak inhibition against the fungi Aspergillus fumigatus, $A$. niger, Candida albicans, C. arriza, C. crusei, Penicillium sp., Rhizopusoryzae, Saccharomyces cerevisiae and Trichoderma viride (Nick et al., 1995a; Wiart et al. al., 2004; Haque et al., 2008; Apu et al., 2010; Smitha et al., 2012). Seven types of triterpenoids from the Dillenia plant have been shown to have antimicrobial action (Nick et al., 1995b; Ragasa et al., 2009). Strong growth inhibition against Escherichia coli, Bacillus subtilis and Micrococcus luteushas been demonstrated by Dillenia papuana (Nick et al., 1995b). The same growth inhibition of Dillenia philippinensis was also reported against E. coli, Pseudomonas aeruginosa, Staphylococcus aureus, and B. subtilis (Ragasa et al., 2009). These findings suggest that the Dillenia plant has potential as an antimicrobial agent supporting its traditional use for the therapeutic treatment of microbial infections related to diseases such as diarrhea, dysentery, septic chemical infections and skin-related diseases (Sabandar et al., 2016).

\section{Utilization of Dillenia spp.}

Dillenia species have been widely used as medicinal plants by indigenous peoples in South and Southeast Asian countries (Lim, 2012), including India, Nepal, Sri Lanka, Bangladesh, Laos, Thailand, Vietnam, Malaysia, Indonesia, the Philippines, and Papua New Guinea. Almost all parts of the Dillenia plant have traditionally been used for medicinal purposes. Fresh and dry ingredients from various parts of the Dillenia plant are processed into stew, poultices, fruit juices and mucus for the treatment of diarrhea, wounds, cancer, diabetes, fever, cough, rheumatism, urinary disorders, skin diseases, and aches, as well as hair tonics. D. excelsa, D. ovata, and $D$. parviflorahave traditionally been used to cure diarrhea (Burkill, 1966; Srithi et al., 2009; Quattrocchi, 2012). Skin-related diseases such as leukoderma, skin itching, skin rashes, and eczema can be treated using the leaves, fruits, and bark of $D$. andamanica, D. indica, D. ovata, and D. pentagyna (Prasad et al., 2008 ;Boer et al., 2012; Quattrocchi, 2012; Bhat et al., 2014). In addition, the bark of $D$. aurea and D. parviflora, as well as the leaves of $D$. suffruticosa, in the form of a paste or poultice are applied to the skin to heal wounds (Mat-Salleh\&Latiff, 2002; Quattrocchi, 2012; Junsongduang et al., 2014). Juice and stew of fruit and stem bark, as well as the leaves of $D$. indica, $D$. pentagyna, and $D$. suffruticosa, are used daily to reduce cancer growth, particularly breast and stomach cancer (Ahmad \&Holdsworth, 1995; Sharma et al., 2001; Das et al., 2008; Prasad et al., 2008; Rosangkima et al., 2008; Dubey et al., 2009). In addition, fruit juices of $D$. indica and $D$. philippinensis were given orally to cure fever and cough symptoms (Angami et al., 2006; Macahig et al., 2011; Quattrocchi, 2012). Mixed fruit and petal juice of $D$. indica and powdered stem bark of $D$. pentagyna is given daily for the treatment of diabetes (Dubey et al., 2009; Pavani et al., 2012; Ripunjoy et al., 2013). During pregnancy, the root of $D$. indica is often used to abort the uterus (Quattrocchi, 2012), while the bark of $D$. papuana and D. pentagyna is used to assist labor during labor and to avoid infection after delivery. (Nick et al., 1994; Dubey et al., 2009). Processed D. pentagyna and D. suffruticosa in the form of a paste applied to the joint area to relieve rheumatism (Quattrocchi, 2012; Hanum \& Hamzah, 1999). In addition, the juice and fruit mucus of $D$. indica, $D$. pentagyna and D. philippinensis are used to clean hair, treat hair loss and eliminate dandruff (Saikia et al., 2006; Macahig et al., 2011; Rahman et al., 2011a ). Dillenia fruit with sweet and sour taste, consumed directly or juiced with sugar as a fresh and healthy drink. In addition, the bark and roots of some Dillenia plants were reported to be neutralizers of food poisoning (Grosvenor et al., 1995b; Islam et al., 2014).

In conclusion, the fruit extract of $D$. serrata grown in the Bali Botanic Garden has the ability as an antioxidant with very weak activity. The antioxidant activity of fresh fruit extracts was higher than that of dried fruit extracts. Extract of $D$. serrata is effective in inhibiting the growth of Pseudomonas aeruginosa, Staphylococcus aureus, and Streptococcus mutans but it is not effective in inhibiting the growth of Candida albicans and Salmonella typhimurium.

\section{Acknowledgement}

This research was funded by DIPA Botanical Garden "EkaKarya" Bali LIPI. All authors state that I Putu Agus Hendra Wibawa is the main contributor to this paper, while I Nyoman Lugrayasa and Sutomo are member contributors.

\section{References}

Ahmad, F.B. \& Holdsworth, D.K., (1995). Traditional medicinal plants of Sabah, Malaysia part III. The Rungus people of Kudat. Int. J. Pharmacogn. 33, 262e264.

Alam, B.M., Rahman, M.S., Hasan, M., Khan, M.M., Nahar, K., \& Sultana, S., (2012). Antinociceptive and antioxidant activities of the Dillenia indica bark. Int. J. Pharmacol. 8 (4), $243 \mathrm{e} 253$.

Angami, A., Gajurel, P.R., Rethy, P., Singh, B., \& Kalita, S.K. (2006). Status and potential of wild edible plants of Arunachal Pradesh.Ind. J. Trad.Knowl.5 (4), 541e550.

Apu, A.S., Muhit, M.A., Tareq, S.M., Pathan, A.H., Jamaluddin, A.T.M., \& Ahmed, M., (2010). Antimicrobial activity and brine shrimp lethality bioassay of the leaves extract of Dillenia indica Linn. J. Young Pharm. 2 (1), 50e53.

Bandara, C.J., Anura W., Bandara B.M.R., Karunaratne D.N, Wijesundara D.S.A., \& Karunaratne, (2015). Chemistry and Bioactivity of Compound of Genus Schumacheria and its close chemataxonomic relationship to genus Dillenia. Journal of Chemical and Pharmaceutical Research, 2015 7(10) : 586-592. Researc Artikel ISSN : 0975-7384 CODEN (USA):JPRCS.

Bauer, A. W., Kirby, W. M. M., Sherris, J.C., \& Turck M.. (1966). Antibiotic susceptibility testing by a standardized single disk method. Am. J. Clin. Pathol. 36:493-496.

Bhat, P., Hegde, G.R., Hegde, G., \& Mulgund, G.S. (2014). Ethnomedicinal plants to cure skin diseases e an account of the traditional knowledge in the coastal parts of Central Western Ghats, Karnataka, India. J. Ethnopharmacol. 151, $493 \mathrm{e} 502$. 
Boer, H.J., Lamxay, V., \& Bjork, L., (2012). Comparing medicinal plant knowledge using similarity indices, a case of the Brou, Saek and Kry in Lao PDR. J. Ethnopharmacol. 141, $481 \mathrm{e} 500$.

Burkill, I.H. (1966). A Dictionary of the Economic Products of the Malay Peninsula. Ministry of Agriculture and Cooperatives, Kuala Lumpur, Malaysia, pp. 821e822.

Cantın, C.M., Minas, I.S., Goulas, V., Jimenez, M., Manganaris, G.A., \& Michailides T.J. (2012). Sulfur dioxide fumigation alone or in combination with $\mathrm{CO} 2$-enriched atmosphere extends the market life of highbush blueberry fruit. Postharvest Biol Technol 67:84-91.

Cao, G., Booth, S.L., Sadowski, J.A., \& Prior, R.L. (1998). Increase in human plasma antioxidant capacity after consumption of controlled diets high in fruits and vegetables. American Journal of Clinical Nutrition, 68, 1881-1887.

Chairunnisa, S., Wartini, N.M., \& Suhendra L. (2019). Pengaruh Suhu dan Waktu Maserasi terhadap Karakteristik Ekstrak Daun Bidara (Ziziphus mauritiana L.) sebagai Sumber Saponin. Jurnal Rekayasa dan Manajemen Agroindustri Vol. 7, No. 4, 551-560, Desember 2019 ISSN : 2503-488X

Chow, S.T, Chao, W.W., \& Chung, Y.C. (2003). Antioxidative Activity and Safety of $50 \%$ Ethanolic Red Bean Extract (Phaseolusraditus L. VarAurea). Journal of Food science. 68 (1): 21-25.

Crespo, P., Gin'e B.J., Terry L.A., \& Carlen, C. (2010). Characterisation of major taste and health-related compounds of four strawberry genotypes grown at different Swiss production sites. Food Chem 122:16-24.

Das, A.K., Dutta, B.K., \& Sharma, G.D., (2008). Medicinal plants used by different tribes of Cachar district. Assam. Ind. J. Trad. Knowl. 7 (3), 446e454.

Dickison, W.C., (1979). A note on the wood anatomy of Dillenia (Dilleniaceae). Iawa Bull. 2e3, 57e60.

Dubey, P.C., Sikarwar, R.L.S., Khanna, K.K., \& Tiwari, A.P., (2009). Ethnobotany of Dillenia pentagyna Roxb. In: Vindhya Region of Madhya Pradesh, India. Nat. Prod. Radiance, vol. 8, pp. 546e548.

Fu, C., Yang, D., Peh,W.Y.E., Lai, S., Feng, X., \& Yang, H., (2015). Structure and antioxidant activities of proanthocyanidins from elephant apple (Dillenia indica Linn.). J. Food Sci. 80 (10), 2191e2199.

Gandhi, D., \& Priti, M. (2013). Dillenia indica Linn and Dillenia pentagyna Roxb.: Pharmacognostic, Phytochemical and Therapeutic aspect. Journal of Applied Pharmaceutical Science Vol. 3(11). Pp 134-142.

Grosvenor, P.W., Gothard, P.K., Mc William, N.C., Supriono, A., \& Gray, D.O., (1995a). Medicinal plants from Riau Province, Sumatra, Indonesia. Part 1.Uses. J. Ethnopharmacol. 45, $75 \mathrm{e} 95$.

Grosvenor, P.W., Supriono, A., \& Gray, D.O., (1995b). Medicinal plants from Riau Province, Sumatra, Indonesia. Part 2, antibacterial and antifungal activity. J. Ethnopharmacol. 45, $97 \mathrm{e} 111$

Hanum, I.F., \& Hamzah, N., (1999). The use of medicinal plant species by the Temuan Tribe of Ayer Hitam forest, Selangor, Peninsular Malaysia. Pertanika J. Trop. Agric. Sci. 22 (2), $85 \mathrm{e} 94$.

Haque, M.E., Islam, M.N., Hossain, M., Mohamad, A.U., Karim, M.F., \& Rahman, M.A. (2008). Antimicrobial and cytotoxic activities of Dillenia pentagyna. Dhaka Univ. J. Pharm. Sci. 7 (1), 103e105.

Hasniarti (2012). Studi Pembuatan Permen Buah Dengen (Dillenia serrata Thunb). Skripsi Program Studi Ilmu dan Teknologi Pangan Jurusan Teknologi Pertanian Fakultas Pertanian Universitas Hasanudin Makassar.

Heyne, K. (1987). Tumbuhan Berguna Indonesia, jil. 3: 1360-63. Yay. Sarana Wana Jaya, Jakarta.

Hoogland, R.D., (1952). A revision of the genus Dillenia. Blumea 7 (1), $1 \mathrm{e} 306$.

Howard L, Clark J, \& Brownmiller C. (2003). Antioxidant capacity and phenolic content in blueberries as affected by genotype and growing season. J Sci Food Agric 83:1238-1247.

Illing, I., Safitri W. \& Erfiana, (2017). Uji Fitokimia Ekstrak Buah Dengen. Jurnal Dinamika hal.66 -84 Vol. 08 No. 1.
Ilma, N., (2012). Studi Pembuatan Dodol Buah Dengen (Dillenia serrata Thunb). Skripsi Program Studi Ilmu dan Teknologi Pangan Jurusan Teknologi Pertanian Fakultas Pertanian Universitas Hasanudin Makassar.

Irnawati, M.P., Riska M. \& Sarnayani, (2017). Penetapan Kadar Vitamin C dan Uji Aktivitas Antioksidan Sari Buah Songi (Dillenia serrataThunb) Terhadap Radikal DPPH. Parmacon Jurnal Ilmiah Farmasi-UNSRAT Vol. 6 No.2 Mei 2017 ISSN $2302-2493$

Islam, M.K., Saha, S., Mahmud, I., Mohamad, K., Awang, K., Uddin, S.J., Rahman, M.M., \& Shilpi, J.A., (2014). An ethnobotanical study of medicinal plants used by tribal and native people of Madhupur forest area. Bangladesh. $J$. Ethnopharmacol. 151, 921e930.

Jaiswal, S., Mansa, N., Prasad, M.S.P., Jena, B.S., \& Negi, P.S., (2014) Antibacterial and antimutagenic activities of Dillenia indica extracts. Food Biosci. 5, 47e53.

Jalil, J., Sabandar, C.W., Ahmat, N., Jamal, J.A., Jantan, I., Aladdin, N.-A., Muhammad, K., Buang, F., Mohamad, H.F., \& Sahidin, I., (2015). Inhibitory effect of triterpenoids from Dillenia serrata (Dilleniaceae) on prostaglandin E2 production and quantitative HPLC analysis of its koetjapic acid and betulinic acid contents. Molecules 20, 3206e3220.

Jansen, P.C.M., Jukema, J., Oyen, L.P.A., \& Lingen, T.G., (1992). Dillenia serrata Thunb. In: Verheij, E.W.M., Coronol, R.E. (Eds.), Plant Resources of South-East Asia No 2. Edible Fruit and Nuts. Prosea Foundation, Bogor, p. 328.

Junsongduang, A., Balslev, H., Inta, A., Jampeetong, A., \& Wangpakapattanawong, P., (2014). Karen and Lawa medicinal plant use, uniformity or ethnic divergence. $J$. Ethnopharmacol. 151, 517e527.

Kader, E.M., Abdel, Zeinab T., \& Shakour, (2015). Phytochemical And Cytotoxicity Investigation of Dillenia indica L. Grown in Egypt. World Journal of Pharmaceutical Research vol. 4, Issue 10,334-348.

Kainde, R.P., Ratag, S.P., Tasirindan, J.S., \& Faryanti, D. (2011) Analisis Vegetasi Hutan Lindung Gunung Tumpa. Euginia Vol. 17 No. 3.

Kaur, N., Kishore, L., \& Singh, R., (2016). Antidiabetic effect of new chromane isolated from Dillenia indica L. leaves in streptozotocin induced diabetic rats. J. Funct. Foods 22, $547 \mathrm{e} 555$.

Kerrigan, R.A., Craven, L.A., \& Dunlop, C.R., (2011). Dilleniaeae. In Short, P.S., Cowie, I.D. (Eds.), Flora of the Darwin Region. Northern Territory Herbarium Department of Natural Resources, Enviroment, the Arts and Sport, Australia, pp. 1e19.

Kruger E, Dietrich H, Schopplein E, Rasima E, \& Kurbel P. (2011) Cultivar, storage conditions and ripening effects on physical and chemical qualities of red raspberry fruit. Postharvest Biol Technol 60:31-37.

Lim, T.K., (2012). Dillenia serrata. Edible medicinal and nonmedicinal plants. In: Fruits, vol. 2. Springer, Dordrecht, p. 3 , $410-420$.

Macahig, R.A.S., Matsunami, K., \& Otsuka, H., (2011). Chemical studies on an endemic Philippine plant, sulfated glucoside and seco-A-ring triterpenoids from Dillenia philippinensis. Chem. Pharm. Bull. 59, 397e401.

Margaretta, S., Handayani, N. Indraswatidan \& H. Hindraso. (2011). Estraksi senyawa phenolics Pandanusa maryllifolius Roxb. sebagai antioksidan alami. Widya Teknik. 10(1):21-30.

Mat-Salleh, K., \& Latiff, A., (2002). Tumbuhan Ubatan Malaysia. Universiti Kebangsaan Malaysia, Bangi, pp. 208e210.

Mustafa, S.W., (2017). Pengolahan Buah Dengen Sebagai Bahan Dasar Pembuatan Sirup Buah Dengen. Sekolah Tinggi Ilmu Ekonomi Muhamadiyah Palopo. Prosiding Seminar Nasional Vol. 03 Nomor 1 ISSN $2443-1109$.

Nick, A., Wright, A.D., Sticher, O., \& Rali, T., (1994). Antibacterial triterpenoid acids from Dillenia papuana. J. Nat. Prod. 57, $1245 \mathrm{e} 1250$

Nick A, Anthony D.W., Topul R. \& Sticher, O., (1995). Antibacterial Triterpenoids From Dlllenia papuana And Their StructureActivity Relationship. PhytochemistryVol 40, No. 6 pp 1691-1695

Nick, A., Rali, T., \& Sticher, O., (1995a). Biological screening of traditional medicinal plants from Papua New Guinea. $J$. Ethnopharmacol. 49, 147e156. 
Nick, A., Wright, A.D., Rali, T., \& Sticher, O., (1995b). Antibacterial triterpenoids from Dillenia papuana and their structureactivity relationships. Phytochem 40, 1691-1695.

Ningsih, D.R., (2017). Ekstrak daun mangga (Mangifera indica L.) sebagai antijamur terhadap jamur Candida albicans dan identifikasi golongan senyawanya. Jurnal Kimia Riset, 2(1), 61-68.

Pavani, M., Rao, M.S., Nath, M.M., \& Rao, C.A., (2012). Ethnobotanical explorations on anti-diabetic plants used by tribal inhabitants of Seshachalam forest of Andhra Pradesh, India.Indian J. Fund. Appl. Life. Sci. 2 (3), 100e105.

Pitopang, R., \& Ihsan M., (2014). Biodiversitas Tumbuhan di Cagar Alam Morowali Sulawesi Tengah. Online Jurnal of Natural Science, Vol. 3(3) : 287-286 ISSN: 2338-0950.

Prasad, P.R.C., Reddy, C.S., Raza, S.H., \& Dutt, C.B.S., (2008). Folklore medicinal plants of North Andaman Islands, India. Fitoterapia 79, 458e464.

Quattrocchi, U.F.L.S., (2012). CRC World Dictionary of Medicinal and Poisonous Plants. CRC Press, New York, pp. 1407e1408.

Ragasa, C.Y., Alimboyoguen, A.B., \& Shen, C.C., (2009). Antimicrobial triterpenes from Dillenia philippinensis. Philipp. Sci. 46, $78 \mathrm{e} 87$.

Rahman, M.D., Rahman, M., Islam, M.M., \& Reza, M.S., (2011a). The importance of forests to protect medicinal plants, a case study of Khadimnagar National Park, Bangladesh. IJBSESM 7, 283e294.

Rahman, M.S., Shams-Ud-Doha, K.M., \& Rahman, R., (2011b). Antidiarrhoeal activity of the leaf and fruit extracts of Dillenia indica. Int. J. Biosci. 1 (6), 39e46.

Ripunjoy, S., (2013). Indigenous knowledge on the utilization of medicinal plants by the Sonowal Kachari Tribe of Dibrugarh district in Assam, North-East India.Int. Res. J. Biol. Sci. 2 (4), $44 \mathrm{e} 50$.

Rosangkima, G., Rongpi, T., \& Prasad, S.B., (2008b). Effect of Dillenia pentagyna extract on sialic acid content and agglutinability of normal and tumor cells with concanavalin $\mathrm{A}$ and wheat germ agglutinin. Int. J. Zool. Res. 4 (4), $203 \mathrm{e} 213$.

Rugayah, A., Martawijaya, J., Ilic, \& Lemmens, R.H.M.J., (1995). Dillenia L. in R.M.H.J. Lemmens, I. Soerianegara and W.C. Wong (eds.). Timber Trees: Minor commercial timber. Plant Resources of South-East Asia (PROSEA) 5(2): 172184.

Sabandar, C.W., Jalil J.i, Norizan A., \& Aladdin N.A., (2016). Medicinal uses, chemistry and pharmacology of Dillenia species (Dilleniaceae). Phytochemistry

https://dx.doi.org/10.1016/j.phytochem.2016.11.010

Saha, D., \& Sundriyal, R.C., (2012). Utilization of non-timber forest products in humid tropics: implications for management and livelihood. For.Policy Econ.14, 28e40.

Saikia, A.P., Ryakala, V.K., Sharma, P., Goswami, P., \& Bora, U., (2006). Ethnobotany of medicinal plants used by Assamese people for various skin ailments and cosmetics. $J$. Ethnopharmacol. 106, 149e157.

Sharma, H.K., Chhangte, L., \& Dolui, K., (2001). Traditional medicinal plants in Mizoram, India. Fitoterapia 72, $146 \mathrm{e} 161$.

Smitha, V.P., Ch, M.M., Kandra, P., Sravani, R., \& Akondi, R.B., (2012). Screening of antimicrobial and antioxidant potentials of Acacia caesia, Dillenia pentagyna and Buchananialanzan from Maredumilli forest of India. $J$. Pharm. Res. 5 (3), 1734e1738.

Srithi, K., Balslev, H., Wangpakapattanawong, P., Srisanga, P., \& Trisonthi, C., (2009). Medicinal plant knowledge and its erosion among the Mien (Yao) in northern Thailand. $J$. Ethnopharmacol. 123, 335e342.

Syahruni, R., \& Nur. S., (2015). Identifikasi Komponen Kimia Dan Uji Daya Antioksidan Ekstrak Buah Dengen (Dillenia serrata Thunbr.) JF FIK UINAM Vol.3 No.4 2015

Wang, S.Y., \& Lin, H.S., (2000). Antioxidant activity in fruits and leaves of blackberry, raspberry, and strawberry varies with cultivar and developmental stage. J Agric Food Chem 48:140-146.

Wiart, C., Mogana, S., Khalifah, S., Mahan, M., Ismail, S., Buckle, M., Narayana, A.K., \& Sulaiman, M., (2004). Antimicrobial screening of plants used for traditional medicine in the state of Perak, Peninsular Malaysia. Fitoterapia 75, 68e73.

Windardi, F.I., Rahayu, M., Uji, T., \& Rustiami, H., (2006). Pemanfaatan tumbuhan sebagai bahan obat oleh masyarakat lokal suku Muna di kecamatan Wakarumba, Kabupaten Muna, Sulawesi Utara. Biodiversitas 7, 333e339.

You, Q., Wang, B., Chen, F., Huang, Z., Wang, X., \& Luo, P.G., (2011). Comparison of anthocyanins and phenolics in organically and conventionally grown blueberries in selected cultivars. Food Chem. 125, 201-208.

Yuliantari, N.W.A., Widarta, I.W.R., \& Permana, I.D.G.M., (2017). Pengaruh suhu dan waktu ekstraksi terhadap kandungan flavonoid dan aktivitas antioksidan daun sirsak (Annona muricata L.). Jurnal Teknologi Pangan. 4(1):35-42. 